Anna Kulig (architak@wp.pl)

Krystyna Romaniak (krystynaromaniak@gmail.com)

Instytut Projektowania Budowlanego, Wydział Architektury, Politechnika Krakowska

\title{
Badania naukowe zabytków platformą współpracy różnorodnych środowisk
}

\section{Scientific research of monuments as a different environmental cooperation platform}

\begin{abstract}
Streszczenie
W ramach działalności naukowo-badawczej pracownicy Wydziału Architektury Politechniki Krakowskiej podejmują różnorodne zagadnienia związane z dziedzictwem architektury. Modernizacje, remonty, renowacje wymagają specjalistycznych umiejętności i znajomości technik już niestosowanych we współczesnym budownictwie, niemal zapomnianych. W pracy przedstawiono rezultaty badań obiektów historycznych, realizowanych przy współpracy z muzeami oraz firmami inwentaryzacyjnymi i komputerowymi. Przeprowadzono pomiary sklepień gotyckich, tworząc ich wirtualne rekonstrukcje, wykonane w technologii BIM.
\end{abstract}

Słowa kluczowe: sklepienia gotyckie, inwentaryzacja budowlana

\section{Abstract}

As part of the research activities, the employees of the Faculty of Architecture of the Cracow University of Technology undertake various issues related to the heritage of architecture. Modernizations, repairs, renovations require specialized skills and knowledge of techniques no longer used in modern construction, almost forgotten. The paper presents the results of research on historical objects realized in cooperation with museums, inventories and computer companies. Gothic vault measurements were made, creating virtual reconstructions with BIM technology.

Keywords: gothic vaults, construction inventory 


\section{WSTĘP}

Zabytki architektoniczne, będące materialną spuścizną minionych epok, są wielkim zobowiązaniem całego społeczeństwa do zachowania ich i utrzymania w odpowiednim stanie. Konserwatorzy obiektów historycznych podejmują różnego rodzaju działania (konserwację, renowację, rekonstrukcje, zmianę funkcji itp.), których nadrzędnym celem jest przekazanie wartości obiektów kolejnym pokoleniom. Czynności te zgodne są z Konwencją w sprawie ochrony światowego dziedzictwa kulturalnego i naturalnego, w której w artykule 5 zapisano:

W celu zapewnienia możliwie najskuteczniejszej ochrony i konserwacji oraz możliwie najbardziej aktywnej rewaloryzacji dziedzictwa kulturalnego i naturalnego znajdującego się na ich terytorium Państwa będące Stronami niniejszej Konwencji, będą się starały w miarę możliwości i odpowiednio do warunków właściwych dla każdego kraju [...] rozwijać studia i badania naukowe i techniczne oraz doskonalić metody interwencyjne, które pozwolą Państwu sprostać niebezpieczeństwom zagrażającym jego dziedzictwu kulturalnemu lub naturalnemu oraz przedsiębrać odpowiednie środki prawne, naukowe, techniczne, administracyjne i finansowe w celu identyfikacji, ochrony, konserwacji, rewaloryzacji i ożywiania lub odtwarzania tego dziedzictwa ${ }^{1}$.

Problem konserwacji i restauracji jest złożony w praktyce ze względu na konieczność działań interdyscyplinarnych. Prawidłową pracę konserwatorską można wykonać, sumując wiedzę specjalistów różnych branż. Sposoby postępowania zależą od indywidualnego zabytku, dlatego nie ma jednej ogólnej zasady postępowania².

Modernizacje, remonty, renowacje wymagają specjalistycznych umiejętności i znajomości technik już niestosowanych we współczesnym budownictwie, niemal zapomnianych. Badacze architektury podejmują się ich rozpoznania i udokumentowania, formułując zalecenia i zasady prowadzenia prac budowlanych. Zaangażowanie w badania, ochronę unikatowych wartości przez nowe inwentaryzacje, atrakcyjne formy prezentacji, przygotowuje do działań w zabytkach o nieniszczącym charakterze. Wirtualne próby aranżacji, wielowariantowe koncepcje przekształceń ułatwiają dyskusje nad wyborem projektu oraz tworzą pomost porozumienia między inwestorem, projektantem i konserwatorem. Działania naukowe dotyczące zabytków mają charakter ponadczasowy, ich wyniki są często uniwersalne i użyteczne zarówno w czasie bieżącym, jak i przyszłym.

W pracy przedstawiono rezultaty badań obiektów historycznych, realizowanych przy współpracy z muzeami i różnymi firmami. Przeprowadzono pomiary wnętrz budowli gotyckich, w tym sklepień gwiaździstych ${ }^{3}$, tworząc ich wirtualne rekonstrukcje, wykonane w technologii BIM. Uzyskane modele są źródłem kompleksowych informacji nie tylko o geometrii sklepień, ale również o dawnych konstrukcjach i technikach budowlanych.

Zasadniczym celem pracy jest prezentacja badań naukowych w odniesieniu do zróżnicowanych środowisk, w których one przebiegają. Prowadzone dociekania były przede wszystkim platformą współpracy firm związanych z nowoczesnymi technologiami oraz środowiska 
konserwatorów zabytków. W pracy zaakcentowano korzyści płynące z wielozespołowej współpracy. Określono ponadto oczekiwania stawiane instytucjom pozauczelnianym w zakresie włączenia się w badania lub umożliwienia ich przeprowadzenia.

\section{PRZEBIEG BADAŃ DOTYCZĄCYCH GEOMETRII SKLEPIEŃ GOTYCKICH}

Potrzeba znajomości reguł rządzących geometrią sklepień gwiaździstych podyktowana jest kilkoma względami. Pierwszym z nich jest konieczność związana z rekonstrukcjami wnętrz obiektów gotyckich ${ }^{4}$. Niewłaściwa interpretacja źródeł może wpłynąć na błędne wykonanie odtworzenia sklepienia, zaburzającego kompozycję całości. Kolejnym problemem jest brak oryginalnych planów z czasu budowy sklepień oraz rozbieżności w odczytaniu ich kształtu. Ważna jest również potrzeba uaktualnienia inwentaryzacji zabytkowych sklepień, która ze względu na ich dużą wysokość do niedawna była trudna do wykonania.

Wymienione wyżej powody były impulsem podjęcia działań naukowo-badawczych, które przebiegały w kilku etapach, omówionych w kolejnych podrozdziałach.

\subsection{KWERENDA ŹRÓDEt}

Zagadnienia szczegółowe, dotyczące sklepień gotyckich, rzadko były podejmowane w polskiej literaturze. Brak ten dotyczył przede wszystkim opracowań naukowo-badawczych. Zagadnienie to poruszano w opracowaniach dotyczących konserwacji, odbudowy obiektów czy zespołów w formie lakonicznych informacji, zwięzłych uwag, często jedynie w przypisach i aneksach. Do dziś wiele kwestii budowlanych na temat sklepień pozostało nierozstrzygniętych ${ }^{5}$. O problemach realizacyjnych dotyczących odbudowy sklepień wspominała Hanna Pieńkowska, iż: „niestety często ze stratą dla oryginału prościej było całkowicie zburzyć sklepienie i od nowa je odbudować" ${ }^{6}$. Zdarzało się, że uzupełnione fragmenty sklepień zawaliły się, na przykład w kościele św. Jana w Gdańsku oraz w katedrze w Poznaniu. Problemy z rekonstrukcjami wiązały się z niezwykle złożoną budową przestrzenną zarówno podniebienia, jak i układu żeber. Nie istniała pełna klasyfikacja obejmująca wszystkie rodzaje, typy i warianty wzorów. Badacze dziejów architektury próbowali odtworzyć dawne metody i techniki budowy na podstawie różnorodnych śladów - ikonografii, inskrypcji ${ }^{7}$ - bowiem żadne oryginalne średniowieczne rysunki sklepień nie zachowały się w Polsce.

Bezcennym źródłem informacji na temat geometrii sklepień gotyckich okazał się XVII-wieczny traktat gdańskiego architekta Bartla Ranischa. Autor zawarł w nim unikatowy opis wznoszenia oraz inwentaryzację 45 typów sklepień, jakie występowały we wszystkich kościołach gdańskich ${ }^{8}$. Tekst starodruku, podzielony na 75 rozdziałów, poświęcony jest siedmiu monumentalnym kościołom: Mariackiemu, św. Jana, św. Trójcy, św. Katarzyny, św. Piotra i Pawła, św. Brygidy oraz sześciu o mniejszej skali. Do opisu konstrukcji dołączone są rysunki, 
wśród których przeważają wykresy geometryczne przęseł sklepiennych, plany, rzuty, elewacje i rozrysy detali (il. 1). Z dzieła Ranischa korzystali architekci, projektanci rekonstrukcji sklepień, zniszczonych podczas II wojny światowej. Wzorowali się oni na rysunkach przedstawionych w pracy, nie analizując tekstu, napisanego w archaicznym, dziś niezrozumiałym języku. Pierwszym zadaniem badawczym było zatem odczytanie zapisu konstrukcji geometrii sklepień, użytego przez Ranischa. Zrozumienie tej notacji posłużyło do nowej interpretacji i przedstawienia go zgodnie z obowiązującą obecnie konwencją prezentacji obiektów trójwymiarowych. Na tej podstawie zbudowano pierwsze modele wirtualne sklepień, wykonane w programie AutoCAD (il. 2$)^{9}$.

Równolegle prowadzono analizę porównawczą dostępnych źródeł: pisanych, ikonograficznych oraz niepublikowanych dokumentacji architektonicznych. Prowadzono również rozmowy z konserwatorami uczestniczącymi w odtworzeniu sklepień, zniszczonych w wyniku działań wojennych. Praca przebiegała w bibliotekach, archiwach Narodowego Instytutu Dziedzictwa, muzeach i bezpośrednio w obiektach. Korzystano również z informacji dostępnych on-line.

Odczytaną geometrię sklepień porównano z nowatorskimi (jak na tamte czasy) pomiarami wnętrza kościoła św. Jana w Gdańsku, wykonanymi przez firmę fotogrametryczną Dephos za pomocą skaningu laserowego ${ }^{10}$. Z zarejestrowanej chmury punktów zespół pracowników opracował mapę warstwicową oraz orthofotomapy i orthoplany (il. 3). Z map można odczytać deformacje i zaburzenia górnych fragmentów sklepień, wynikające z kilkuwiekowego osiadania konstrukcji. Jednocześnie dostrzega się zachowanie struktury i jednolitej techniki u nasad sklepień, a więc w miejscach połączenia z filarami i ścianami, które nie podlegały takim odkształceniom. Zestawiając wirtualne modele, zbudowane według wskazówek Ranischa, z wynikami pomiarów cyfrowych, uzyskano zgodność kształtu analizowanego sklepienia. Uwiarygodniło to zapis podany przez XVII-wiecznego badacza i było impulsem do dalszych dociekań.

Kolejny etap działań naukowych wiązał się z obserwacjami, których głównym celem było zgromadzenie kompletnych informacji o stanie obecnym sklepień (dokumentacji fotograficznej, technicznej itp.), co wiązało się z bezpośrednią analizą kształtu i stanu zachowania w odniesieniu do przeszłości (zachowanych informacji z dziejów obiektów, w tym zniszczeń wojennych) oraz porównanie istniejących sklepień z wykonanymi modelami wirtualnymi. Analizę przeprowadzono zarówno w obiektach z oryginalnymi wnętrzami, jak i w tych, w których uległy one częściowemu lub całkowitemu zniszczeniu i były odbudowane. Zebrano bogatą dokumentację fotograficzną, która posłużyła do wykonania wstępnych klasyfikacji sklepień gotyckich ${ }^{11}$. Miejscem prowadzonych badań były kościoły, muzea, zamki, archiwa konserwatorskie na Pomorzu, Dolnym Śląsku i w Krakowie (il. 4). Najwięcej uwagi poświęcono kościołom i klasztorom gdańskim, ze względu na największą w skali Europy powierzchnię sklepień rekonstruowanych oraz ze względu na fakt wykonania dla nich nowatorskich modeli komputerowych. 
Szczególnym obiektem zainteresowań naukowych stało się również Muzeum Zamkowe w Malborku. Powodem było niezwykłe bogactwo sklepień gwiaździstych i palmowych oraz pozostające wówczas w ruinie sklepienie w kościele zamkowym. Nieistniejące sklepienie oraz wiedza na temat możliwego sposobu jego konstrukcji były impulsem do wykonania jego cyfrowego modelu. Postępowanie to zakończyło się sukcesem. Zaproponowane rozwiązanie w pełni dopasowało się do zachowanych zakończeń żeber sklepiennych. Uwiarygodniło to po raz kolejny poprawność stosowanej przez badaczy metody ${ }^{12}$ (il. 5).

\subsection{PROJEKT BADAWCZY FINANSOWANY PRZEZ NCN}

Dalsze dociekania naukowe, dotyczące sklepień gotyckich, prowadzono w ramach projektu badawczego 2011/01/D/HS 2/202288, finansowanego przez Narodowe Centrum Nauki pod nazwą „Problem dokumentowania, modelowania i rekonstrukcji sklepień gotyckich". Jednym z zadań podejmowanych w ramach przyznanych środków było wykonanie nowych inwentaryzacji wnętrz obiektów zabytkowych w celu odczytania kształtu sklepień i określenia reguł geometrycznych stosowanych przez dawnych budowniczych. Pomiary przeprowadziła firma BIMPoint, która wykorzystała do tego celu urządzenie pomiarowe Flexijet ${ }^{13}$. Sporządziła ona bardzo dokładne modele wykonane w technologii BIM (stosując program ArchiCAD). Przeprowadzono inwentaryzację oryginalnych sklepień w zabytkowych obiektach krakowskich: Colegium Maius (Libraria), kościół dominikanów (prezbiterium), kościół franciszkanów (krużganki) oraz w Malborku - Letni Refektarz w Muzeum Zamkowym ${ }^{14}$. W ramach projektu opracowano wiele wizualizacji fotorealistycznych oraz schematycznych przedstawień struktur sklepiennych, stosując nowoczesne techniki cyfrowe. Efektem końcowym badań była monografia ${ }^{15}$, w której przedstawiono reguły i sposoby konstrukcji przekryć gotyckich wnętrz.

\subsection{KONCEPCJA REKONSTRUKCJI SKLEPIENIA W KOŚCIELE ZAMKOWYM W MALBORKU I JEJ UŻYTECZNOŚĆ W PRACACH REKONSTRUKCYJNYCH}

W 2014 roku Muzeum Zamkowe w Malborku uzyskało środki na dofinansowanie projektów do programu Konserwacja i rewitalizacja dziedzictwa kulturowego w ramach Mechanizmu Finansowego Europejskiego Obszaru Gospodarczego i Norweskiego Mechanizmu Finansowego na lata 2009-2014. Kwota, w wysokości 26 milionów złotych, miała być przeznaczona również na odbudowę sklepień w kościele zamkowym Najświętszej Marii Panny, które od czasów II wojny światowej pozostawały w ruinie. Ze względu na prowadzony temat badawczy, zgodny z potrzebami Muzeum, Anna Kulig została zaproszona do udziału w odbudowie jako konsultant. Wykonane studium sklepień wykorzystano do celów praktycznych (wykonawczych) oraz prezentacji wyników i dyskusji w gronie kustoszy. Opracowano wariantowe projekty odtworzenia sklepienia gwiaździstego w kościele zamkowym w Malborku 
(il. 6), łącznie z różnymi propozycjami kolorystyki. Wykorzystując skaning laserowy ścian wnętrza kościoła oraz relikty żeber i pól wraz z fragmentami XIV-wiecznego wystroju rzeźbiarskiego, wykonano wirtualny model przęseł, dopasowanych do istniejących pozostałości. Propozycję tę upubliczniono, poddając szerokiej dyskusji i akceptacji, co wpłynęło na uściślenie geometrii sklepień w odniesieniu do kształtu historycznego.

\section{PODSUMOWANIE}

Zaprezentowane w pracy badania naukowe, dotyczące geometrii sklepień gotyckich, są przykładem działań toczących się zarówno na terenie uczelni, jak i w szeroko rozumianym środowisku. Sama materia analiz, w postaci sklepień, badana była na terenie nieomal całej Polski (europejskie przykłady rozważono na podstawie publikacji i dostępnej dokumentacji). Bezpośredni kontakt i dostęp do obiektów zamkowych możliwy był dzięki życzliwości i otwartości wielu instytucji i środowisk. Do sukcesu badań przyczyniała się współpraca z różnymi firmami (Dephos, BIMpoint, Graphisoft, Autodesk), które swoim sprzętem i programami komputerowymi wspierały te działania. Korzyść z podejmowanej aktywności była obustronna: z jednej strony badacze mieli możliwość przeprowadzenia analiz, które poszerzyły dotychczasową wiedzę zarówno teoretyczną, jak i praktyczną na temat sklepień gotyckich, z drugiej strony - instytucje i różne środowiska mogły korzystać z wyników tych działań (na przykład Muzeum Zamkowe w Malborku uzyskało nową inwentaryzację sklepień Letniego Refektarza oraz korzystało z konsultacji w zakresie geometrii sklepień, rekonstruowanych w kościele zamkowym). Firma BIMpoint nawiązała dłuższą współpracę z Muzeum Zamkowym po zaprezentowaniu trójwymiarowego modelu inwentaryzowanego Letniego Refektarza.

Na podstawie wieloletnich badań, dotyczących obiektów historycznych, prowadzonych w różnych środowiskach, można zauważyć problem wymiany informacji między wszystkimi stronami zainteresowanymi losami zabytków. Rozproszenie środowiska oraz wąska specjalizacja badaczy powoduje, że ich kompetencje znane są nielicznemu gronu osób, najczęściej związanemu z wyższymi uczelniami. Stąd popierać należy wszelkie inicjatywy służące integracji zróżnicowanych środowisk i będące jednocześnie miejscem ich spotkania oraz przepływu informacji (konferencje, warsztaty itp.). Wzajemne poznanie potrzeb i oczekiwań wszystkich stron byłoby podstawą współpracy i umożliwiłoby wspólne staranie się o środki finansowe na badania, będące odpowiedzią na konkretne potrzeby środowiska ${ }^{16}$. 
a)

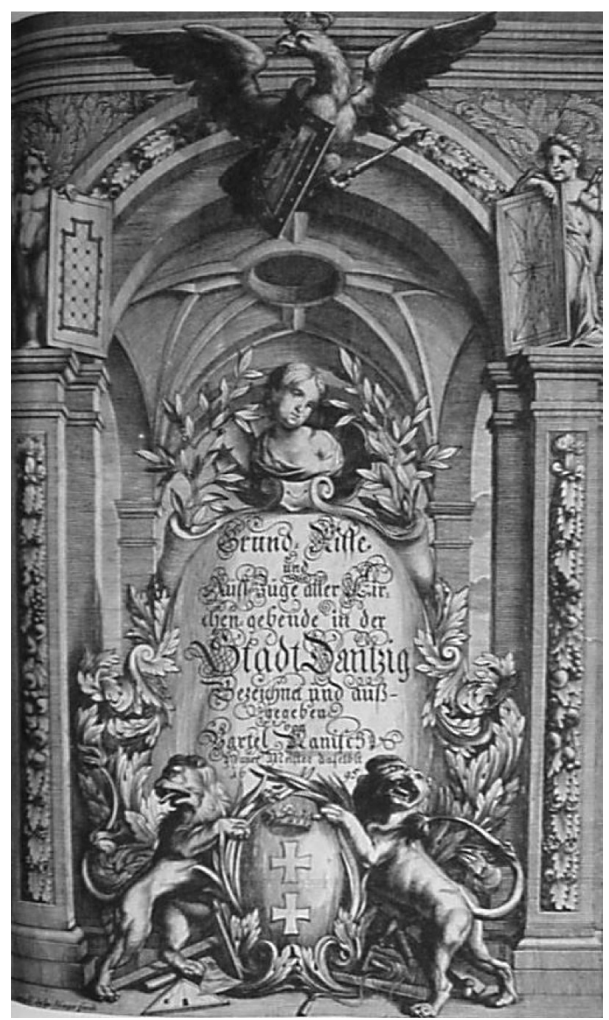

c)
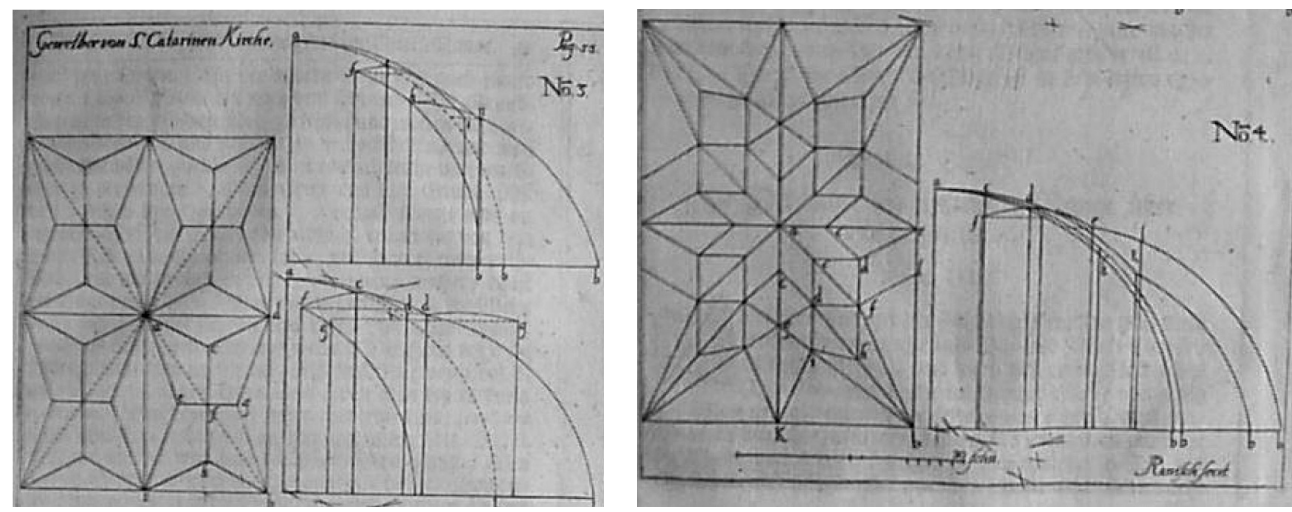

II. 1. Traktat B. Ranischa: a) strona tytułowa, b) kościół św. Katarzyny w Gdańsku: elewacja i rzut, c) zapis konstrukcji żeber

III. 1. Treaty of B. Ranisch: a) front page, b) St. Catherine Church in Gdansk: elevation and projection, c) notation of the rib construction 
a)

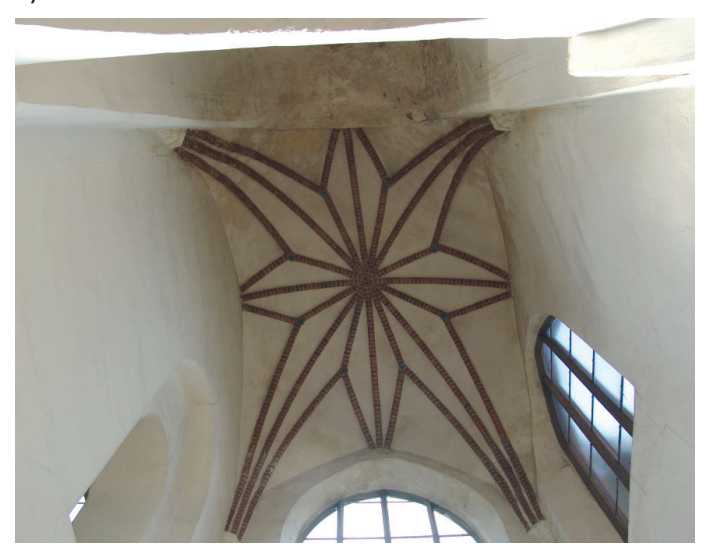

b)

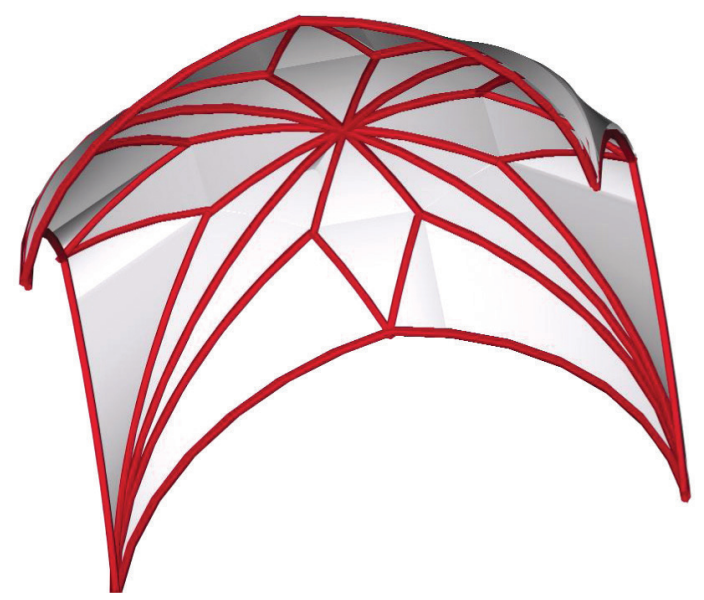

II. 2. Sklepienie gwiaździste z rysunkiem gwiazdy ośmioramiennej: a) kościół św. Katarzyny w Gdańsku (zdjęcie własne), b) model wykonany w programie AutoCad (opracowanie własne)

III. 2. Stellar vault with figure of eight-arm star: a) St. Catherine church in Gdansk (own photo), b) model made in AutoCad (own work) 
a)

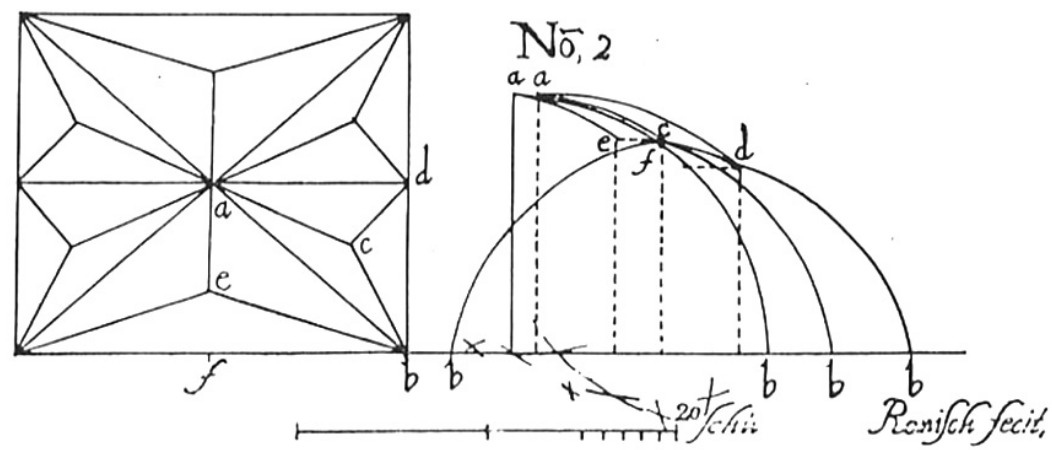

b)

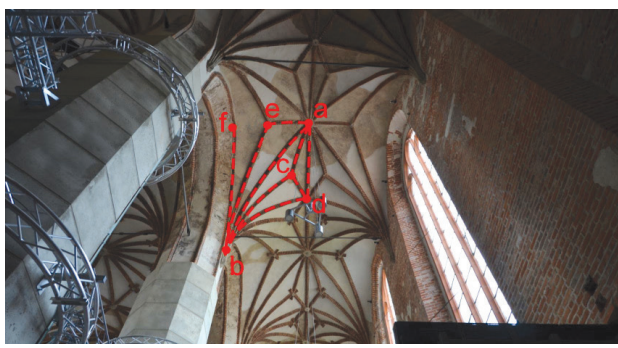

c)

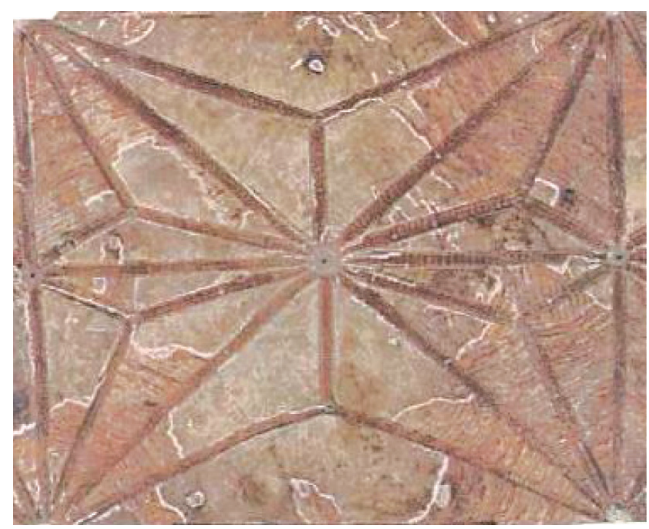

d)

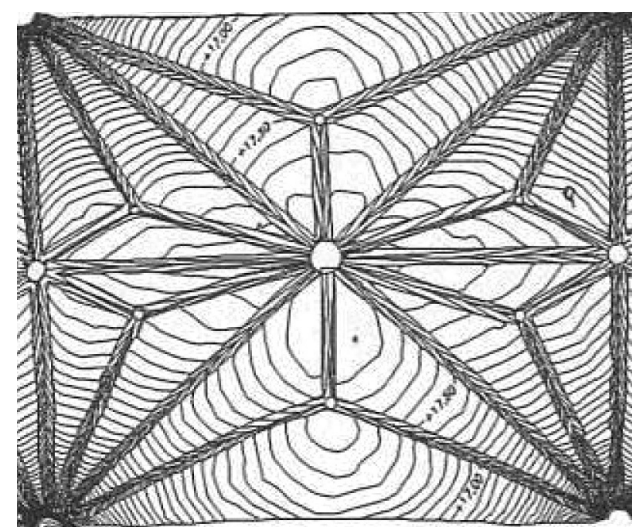

II. 3. Kościół św. Jana w Gdańsku - sklepienie z rysunkiem gwiazdy sześcioramiennej: a) zapis konstrukcji B. Ranischa, b) opis charakterystycznych punktów na widoku wnętrza (zdjęcie własne),

c) orthofotoplan wykonany przez firmę Dephos, d) mapa warstwicowa wykonana przez firmę Dephos

III. 3. St. John church in Gdansk - vault with figure of sixth-arm star: a) notation of B. Ranisch construction, b) description of the characteristic points on the interior view (own photo), c) orthofotoplan made by Dephos, d) contour plan made by Dephos 
a)

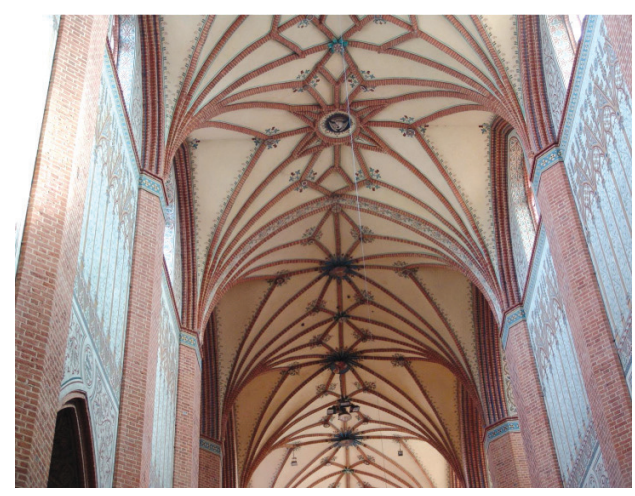

b)

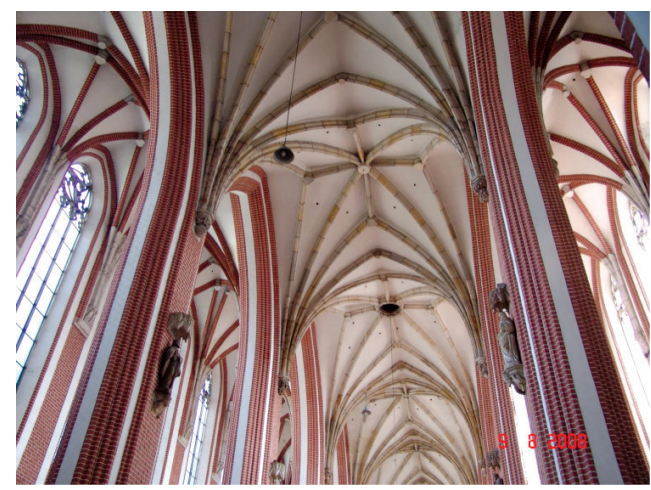

c)

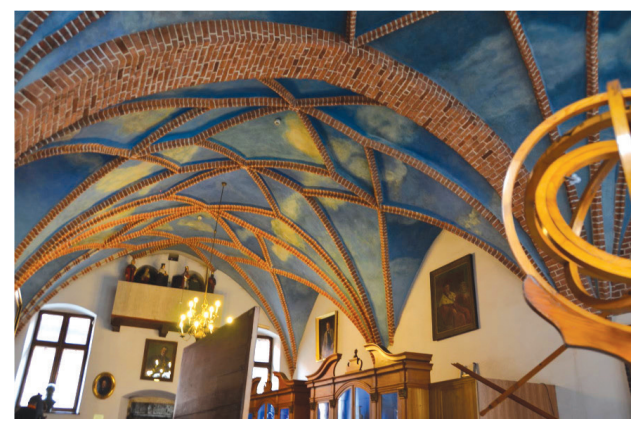

II. 4. Sklepienia gotyckie: a) Bazylika katedralna Wniebowzięcia Najświętszej Maryi Panny w Pelplinie, b) kościół Najświętszej Maryi Panny na Piasku we Wrocławiu, c) Collegium Maius Uniwersytetu Jagiellońskiego w Krakowie (zdjęcie własne)

III. 4. Gothic vaults: a) Cathedral Basilica of the Assumption in Pelplin, b) the church of Virgin Mary on the Sand in Wroclaw, c) Collegium Maius in Cracow (own photos) 
a)

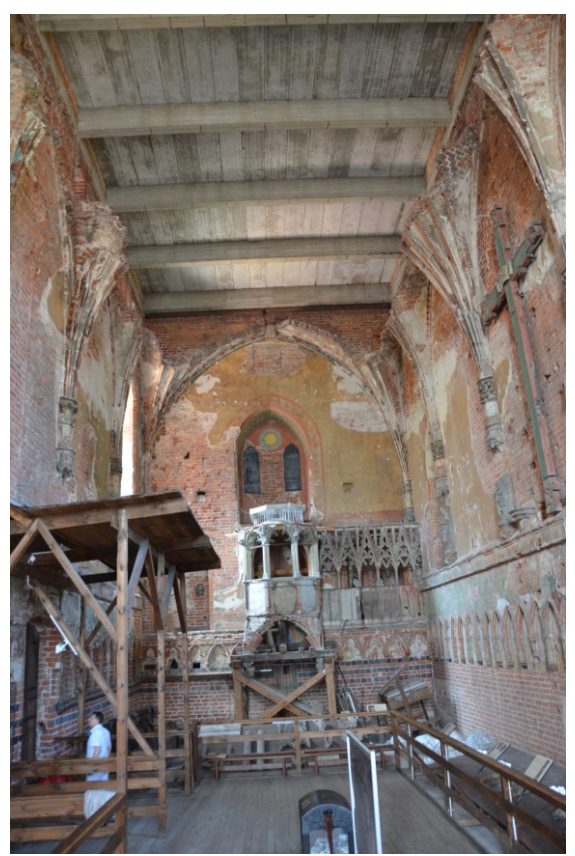

II. 5. Kościół zamkowy w Malborku: a) widok wnętrza z 2008 roku (zdjęcie własne), b) wirtualny model sklepienia (opracowanie własne)

b)

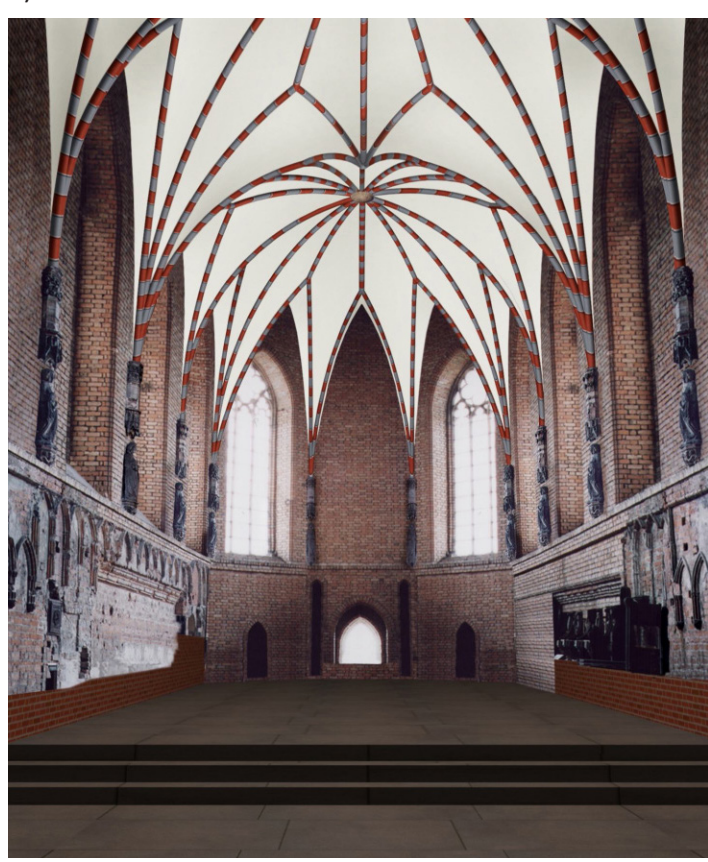
III. 5. Malbork Castle Church: a) interior view, 2008 (own photo), b) virtual model of vault (own work) 
a)

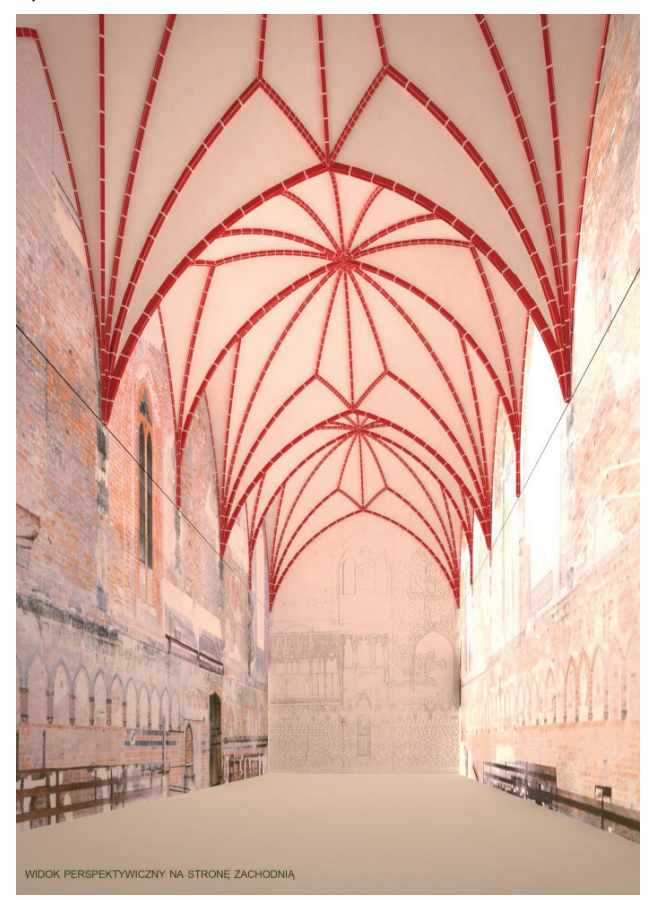

b)

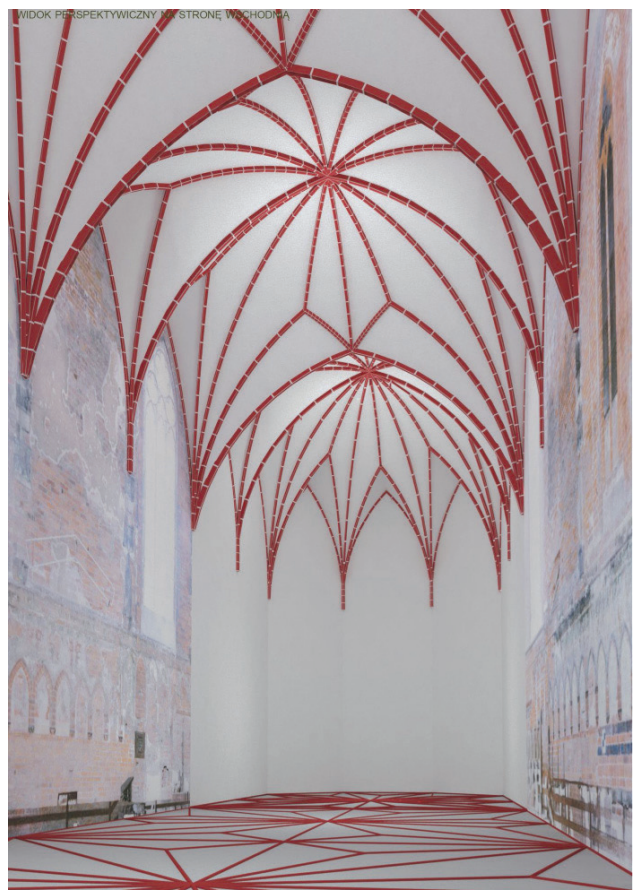

c)

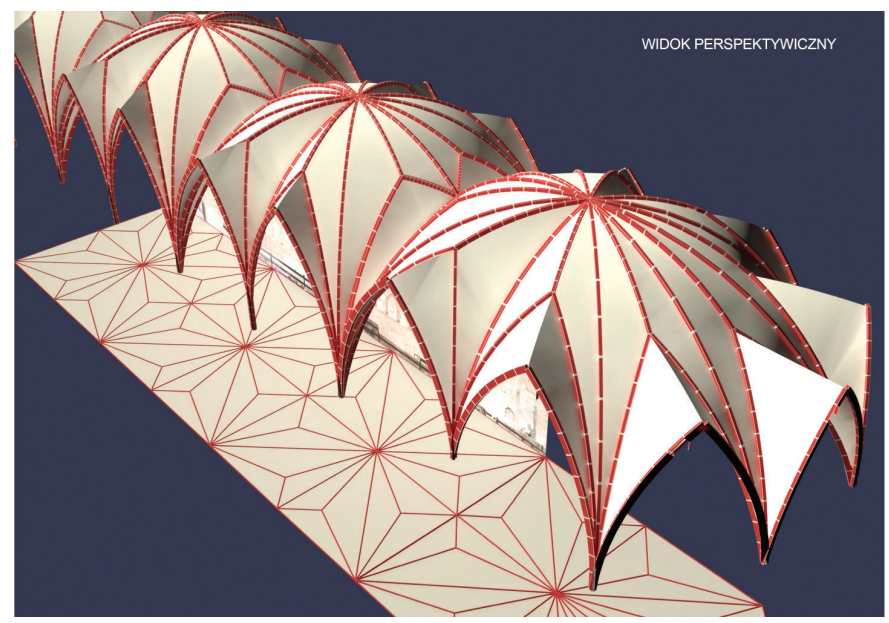

II. 6. Projekt rekonstrukcji sklepienia w kościele NMP na zamku w Malborku - widoki perspektywiczne: a) na stronę zachodnią, b) na stronę wschodnią, c) z góry (opracowanie własne)

III. 6. The vault reconstruction project in the church of the Blessed Virgin Mary at Malbork Castle perspective views: a) west side, b) east side, c) from above (own work) 


\section{PRZYPISY}

1 Konwencja w sprawie ochrony światowego dziedzictwa kulturalnego i naturalnego, Dz.U. 76.32.190, z dnia 30 września 1976 r.

2 Brodzka J., Ciarkowski B., Konserwacja i kreacja architektury: Jan Tajchman i jego działalność, Toruń 2014.

3 Sklepienia gwiaździste to formy przekryć wnętrz obiektów gotyckich. Wznoszone w całej Europie od XII do XVII wieku, zawierają w swoim kształcie rysunek gwiazdy: cztero-, sześcio- czy ośmioramiennej. Ze względu na swój dynamiczny kształt i bogactwo form budzą do dziś zachwyt i podziw.

4 Rekonstrukcja rozumiana jest jako dodanie nowej części (kompozycji) na podstawie zachowanych przekazów, czego konsekwencją winno być uczytelnienie obiektu, przywrócenie dziełu sztuki wyobrażenia o jego dawnym wyglądzie.

5 Kulig A., Metody geometryczne w rekonstrukcji sklepień gotyckich, rozprawa doktorska, Kraków 2006, s. 14-15.

6 Pieńkowska H., Konfrontacje konserwatorskie, „Biuletyn Historii Sztuki”, nr 1, 1970, s. 82-85.

7 Frazik J., Technika średniowiecznych rysunków architektonicznych, „Teka Komisji Urbanistyki i Architektury", 1995, s. 195-203; Wyrobisz A., Budownictwo murowane w Małopolsce XIV i XV wieku, Kraków 1963, s. 97-102.

8 Ranisch B., Beschreibung aller Kirchen-Gebaude der Stadt Danzing, Danzing 1695.

9 Cyfrowe modele sklepień gwiaździstych zaprezentowano w kilku opracowaniach, między innymi w pracach A. Kulig, op. cit.; A. Kulig, K. Romaniak, A Universal Geometrical Method for Reconstruction of Gothic Vaults, Journal for Geometry and Graphics, vol. 12, No. 1, 2008, s. 81-86.

${ }^{10} \mathrm{~W}$ ramach prowadzonych badań pracownicy Politechniki Krakowskiej odwiedzili firmę Dephos i mogli zarówno zapoznać się z wynikami ich inwentaryzacji, jak i bezpośrednio obserwować pracę nad chmurą punktów, będącą efektem wykonanych pomiarów. Firma Dephos przeprowadziła inwentaryzację sklepień na potrzeby konserwacji średniowiecznej polichromii (odsłoniętej fragmentarycznie).

${ }^{11}$ A. Kulig, op. cit., s. 96-135.

12 Ibidem.

${ }^{13}$ Szybkość i dokładność uzyskanych pomiarów, wykonanych w technologii BIM, zaważyła o decyzji o zakupie urządzenia FlexyJet przez Wydział Architektury Politechniki Krakowskiej.

${ }^{14}$ Znajomość reguł geometrii sklepień gotyckich ułatwiła wykonanie pomiarów i modelu Letniego Refektarza w przeciągu jednego dnia. Było to tak szybkie tempo i tak komplek- 
sowy wynik, że firma BIMpoint otrzymała zlecenie na wykonanie inwentaryzacji kolejnych pomieszczeń.

15 Por. A. Kulig, Problem dokumentowania, modelowania i rekonstrukcji sklepień gotyckich, Wydawnictwo Politechniki Krakowskiej, Kraków 2015.

${ }^{16}$ Kustosze zamkowi w Malborku w trakcie prowadzonych rozmów wskazywali możliwość wspólnego starania się o środki finansowe na prowadzenie dalszych badań.

\section{BIBLIOGRAFIA}

Brodzka J., Ciarkowski B., Konserwacja i kreacja architektury: Jan Tajchman i jego działalność, Toruń 2014.

Frazik J., Technika średniowiecznych rysunków architektonicznych, „Teka Komisji Urbanistyki i Architektury", 1995, s. 195-203.

Konwencja w sprawie ochrony światowego dziedzictwa kulturalnego i naturalnego, Dz.U. 76.32.190 z dnia 30 września 1976 r.

Kulig A., Metody geometryczne w rekonstrukcji sklepień gotyckich, rozprawa doktorska, Kraków 2006.

Kulig A., Romaniak K., A Universal Geometrical Method for Reconstruction of Gothic Vaults, "Journal for Geometry and Graphics", vol. 12, No. 1, 2008, p. 81-86.

Kulig A., Problem dokumentowania, modelowania i rekonstrukcji sklepień gotyckich, Kraków 2015.

Pieńkowska H., Konfrontacje konserwatorskie, „Biuletyn Historii Sztuki”, nr 1, 1970, s. 82-85. Ranisch B., Beschreibung aller Kirchen-Gebaude der Stadt Danzing, Danzing 1695.

Wyrobisz A., Budownictwo murowane w Małopolsce XIV i XV wieku, Kraków 1963. 